\title{
A SYSTEMATIC REVIEW OF ANTIGLUCOCORTICOIDS EFFICACY IN THE TREATMENT OF BIPOLAR DISORDER
}

\section{BACKGROUND}

Bipolar Disorder (BD) affects more than $3 \%$ of the world population $^{1}$, with mortality rates 3 times higher than the general population ${ }^{2}$. The patients suffer from pathological mood states ${ }^{3}$ and their neurocognitive performance is often compromised ${ }^{4}$.

It has been established that exposure to stress-inducing events throughout life greatly increases the risk of $\mathrm{BD}^{5}$. The accumulation of excess stress leads to dysfunction of the hypothalamic-pituitaryadrenal (HPA) axis, with the installation of a state of hypercortisolism $^{6}$ and depletion of glucocorticoid receptors ${ }^{7-8}$. These results in the attainment of the self-regulating mechanisms involved in the stress response.

The treatment still has some gaps with $50 \%$ of the treated patients do not reach a complete remission ${ }^{9}$. Given the role that HPA axis dysfunction and, in particular, hypercortisolism play in the etiopathogenesis and worsening of $\mathrm{BD}$, it is understandable the potential that interventions in this area may have in the treatment of BD. The agents most investigated with anti-glucocorticoid activity are mifepristone, ketoconazole, aminoglutethimide, metirapone, dehydroepiandrosterone and mitotane.

\section{AIM}

To compile and analyse the studies that tested the efficacy of antiglucocorticoids in the treatment of BD.

\section{METHODS}

The guidelines of the PRISMA Statement ${ }^{10}$ were followed.

\section{Eligibility Criteria}

Inclusion 1. Studies in humans, both genders, $\geq 18$ y.o. and with diagnoses of type I or II BD (Diagnostic and Statistical Manual of Mental Disorders/DSM or International Classification of Disease/ICD).

Studies that include administration of at least one of the antiglucocorticoids: Ketoconazole, Metirapone, Aminoglutethimide, Mitotane, Mifepristone and Dehydroepiandrosterone. They should simultaneously establish a comparison with placebo, mood stabilizers and/or antidepressants;

3. Studies evaluating the effectiveness of the intervention vs comparator based on at least one of the following outcomes: improving cognitive functions, improving mood symptoms and reducing use of health services;

4. Randomized clinical trials (RCT), cross-over studies and ongoing clinical trials.

Exclusion 1. Studies that include patients diagnosed with other mood disorders (unipolar depression and unipolar mania);

2. Reviews, case reports, case series, editorials, letters, opinions, conference abstracts, books and chapters.

An electronic search on PubMed, Scopus, Isi Web of Science, Cochrane Central Register of Controlled Trials, ClinicalTrials.gov and World Health Organization platforms was performed until 26/02/2019, without time and language restrictions.

The references were imported into the EndNote X8 software. The duplicated references were eliminated and the remaining articles were selected according to the eligibility criteria. Subsequently, a comparative evaluation was made between the included studies, as well as the assessment of the risk of biases, using a Cochrane tool $^{11}$.

\section{RESULTS}

A total of 433 references were found and 49 duplicated articles were eliminated. The 384 remaining were screened according to the title and abstract. From these, 293 references did not meet the eligibility criteria and the full-text of the 91 remaining were screened. After this, 4 final studies (1 RCT, 1 cross-over study and 2 ongoing clinical trials) meet the criteria and were included in the analysis (Tables 1 and 2).

Table 1 - Summary of the finished clinical trials.

\begin{tabular}{|c|c|c|c|c|c|c|}
\hline Reference & $\begin{array}{l}\text { Study } \\
\text { Design }\end{array}$ & $\begin{array}{l}\text { Inclusion } \\
\text { Criteria }\end{array}$ & Sample & Intervention & $\begin{array}{l}\text { Primary } \\
\text { Outcomes }\end{array}$ & Results \\
\hline $\begin{array}{c}\text { Young, A. } \\
\text { H. et al. } \\
2004^{12}\end{array}$ & $\begin{array}{l}\text { Cross- } \\
\text { over } \\
\text { study } \\
\text { (double- } \\
\text { blinded) }\end{array}$ & $\begin{array}{l}\text { Age: } 18-65 \\
\text { y. o. } \\
\text { Depressed } \\
\text { patients } \\
\text { with BD } \\
\text { (DSM-IV) }\end{array}$ & $\begin{array}{l}19 \text { patients } \\
\text { from } \\
\text { tertiary } \\
\text { care units }\end{array}$ & $\begin{array}{l}\text { Mifepristone } \\
600 \mathrm{mg} / \text { day vs } \\
\text { placebo (1 } \\
\text { week duration) } \\
\text { Group change } \\
\text { at } 3 \text { weeks }\end{array}$ & $\begin{array}{c}\text { Spatial } \\
\text { working } \\
\text { memory } \\
\text { (SWM), } \\
\text { verbal } \\
\text { declarative } \\
\text { memory and } \\
\text { mood } \\
\text { symptoms }\end{array}$ & $\begin{array}{l}\text { Mifepristone improved } \\
\text { SWM } 2 \text { weeks after the } \\
\text { treatment } \\
\text { Mifepristone improved } \\
\text { verbal declarative } \\
\text { memory and depressive } \\
\text { symptons but the } \\
\text { difference wasn't } \\
\text { statistically significant }\end{array}$ \\
\hline $\begin{array}{l}\text { Watson, S. } \\
\text { et al. } 2012^{13}\end{array}$ & $\begin{array}{c}\text { RCT } \\
\text { (double- } \\
\text { blinded) }\end{array}$ & $\begin{array}{l}\text { Depressed } \\
\text { patients } \\
\text { with BD } \\
\text { (DSM-IV) }\end{array}$ & $\begin{array}{l}60 \text { patients } \\
\text { from } \\
\text { secundary } \\
\text { care units } \\
+55 \\
\text { healthy } \\
\text { controls }\end{array}$ & $\begin{array}{c}\text { Mifepristone } \\
600 \mathrm{mg} / \text { day vs } \\
\text { placebo (1 } \\
\text { week duration) }\end{array}$ & $\begin{array}{l}\text { Spatial } \\
\text { working } \\
\text { memory } \\
(\mathrm{SWM})\end{array}$ & $\begin{array}{l}\text { Mifepristone improved } \\
\text { SWM } 6 \text { weeks after the } \\
\text { treatment }\end{array}$ \\
\hline
\end{tabular}

The risk of selection, performance and detection biases is uncertain and it is low for the attrition and reporting biases in the cross-over study ${ }^{12}$. In the $\mathrm{RCT}^{13}$ the risk is low for all the biases.

Table 2 - Summary of the ongoing clinical trials (ClinicalTrials.gov).

\begin{tabular}{|c|c|c|c|c|c|c|}
\hline \multirow{2}{*}{ Reference } & \multirow{2}{*}{$\begin{array}{l}\text { Study } \\
\text { Design }\end{array}$} & \multicolumn{2}{|c|}{ Eligibility Criteria } & \multirow{2}{*}{$\begin{array}{l}\text { Sample and } \\
\text { Intervention }\end{array}$} & \multirow{2}{*}{ Outcomes } & \multirow{2}{*}{ Results } \\
\hline & & Inclusion & Exclusion & & & \\
\hline $\begin{array}{c}\text { NCT000436 } \\
54^{14}\end{array}$ & $\begin{array}{c}\text { RCT } \\
\text { (double- } \\
\text { blinded) }\end{array}$ & $\begin{array}{c}\text { Age: } 18-75 \\
\text { y.o. } \\
\text { Severely } \\
\text { depressed } \\
\text { patients with } \\
\text { BD (I or II) }\end{array}$ & $\begin{array}{l}\text { Antidepressants, } \\
\text { zolpidem and } \\
\text { lorapezam } \\
\text { Contraindications } \\
\text { to mifepristone } \\
\text { Neurological and } \\
\text { uncompensated } \\
\text { endocrine } \\
\text { conditions } \\
\text { Substance } \\
\text { dependence }\end{array}$ & $\begin{array}{l}75 \text { inpatients }+ \\
35 \text { healthy } \\
\text { controls } \\
\text { Mifepristone vs } \\
\text { placebo ( } 8 \text { days } \\
\text { duration) }\end{array}$ & $\begin{array}{l}\text { Cognitive } \\
\text { impairment }\end{array}$ & $\begin{array}{c}\text { No data } \\
\text { available } \\
\text { (withdrawn) }\end{array}$ \\
\hline $\begin{array}{c}\text { NCT003591 } \\
25^{15}\end{array}$ & $\begin{array}{c}\text { RCT } \\
\text { (double- } \\
\text { blinded) }\end{array}$ & $\begin{array}{l}\text { Age: } 19-65 \\
\text { y.o. } \\
\text { Depressed } \\
\text { patients with } \\
\text { BD }\end{array}$ & $\begin{array}{l}\text { Contraindications } \\
\text { to mifepristone } \\
\text { Neurological and } \\
\text { uncompensated } \\
\text { endocrine } \\
\text { conditions } \\
\text { Substance } \\
\text { dependence } \\
\text { Patients in risk of } \\
\text { injuring } \\
\text { themselves/others }\end{array}$ & $\begin{array}{c}100 \text { outpatients } \\
+50 \text { healthy } \\
\text { controls } \\
\\
\text { Mifepristone } \\
600 \mathrm{mg} / \text { day vs } \\
\text { placebo } 600 \\
\text { mg/day ( } 1 \\
\text { week duration) }\end{array}$ & $\begin{array}{l}\text { Neurocognitive } \\
\text { performance } \\
\text { (learning and } \\
\text { memory, } \\
\text { attention, } \\
\text { executive } \\
\text { functioning, } \\
\text { and facial } \\
\text { expression) and } \\
\text { mood } \\
\text { symptoms }\end{array}$ & $\begin{array}{l}\text { No data } \\
\text { available } \\
\text { (ongoing) }\end{array}$ \\
\hline
\end{tabular}

\section{DISCUSSION AND CONCLUSION}

This review suggests that evidence has yielded insufficient results to support the implementation of these drugs in the therapeutic approach of bipolar patients.

One of the studies analysed, showed that mifepristone comparing with placebo, improved SWM at 7 week, but not at 3 weeks. Another trial reported benefit of mifepristone at 3 weeks, but the methodological quality of this study is more questionable. The administration of this drug was not associated with significant improvements in other neurocognitive parameters and depressive symptoms.

Future studies with mifepristone are needed to confirm the existing results and other antiglucocorticoid agents should also be tested, considering the positive results that have been obtained in other mood disorders, such as unipolar major depression. 